\title{
Effect of Ginger Powder (Zingiber officinale) on Acid-Base Balance, Rumen and Blood Constituents in Healthy Egyptian Sheep
}

\author{
Mariam Gamal Zaki, Taher Ahmad Barka and Fatma Abd EL-Fattah Tayeb*
}

Department of Medicine and Infectious Diseases, Faculty of Veterinary Medicine, Cairo University, 12211, Giza, Egypt *Corresponding author: fatmatayeb178@gmail.com

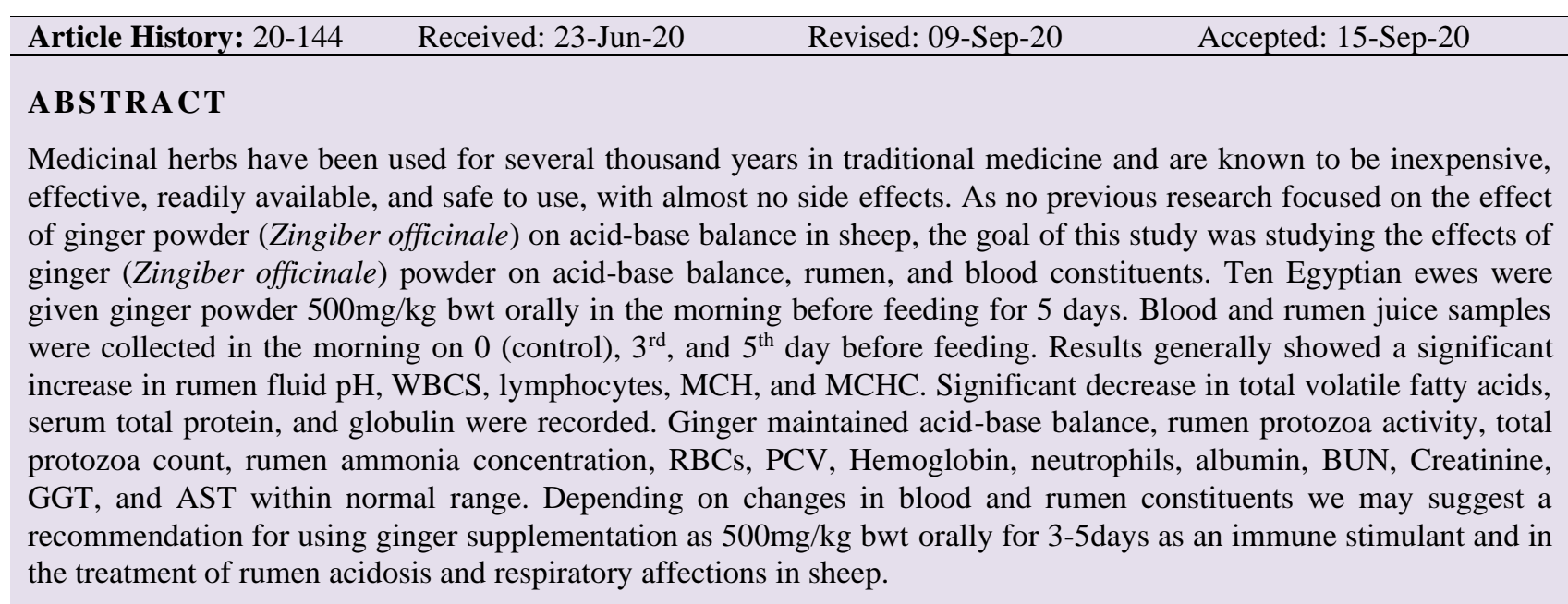

Key words: Sheep, Zingiber officinale, Acid-base balance, Rumen and Blood constituents.

C2020 IJVS - All Rights Reserved

\section{INTRODUCTION}

Sheep are valuable livestock species due to their ability to turn forages into meat and milk that are essential sources of human dietary protein. Sheep are the most common animal (other than avian species) raised in Egypt for meat (FAOSTAT 2018). So, to benefit the human population, it is necessary to enhance and sustain the health and productivity of these animals. The history of medicinal herbs used to cure diseases and improve sheep's overall health with a focus on GIT diseases in small ruminants has been reviewed by (Engel 2007). Herbs and spices are considered to have health benefits such as stimulants for appetite and digestion, anti-microbial action, antiinflammatory action, anti-oxidative action, and immune stimulant activity on animals (Al-Azazi et al. 2018).

Ginger (Zingiber officinale) is one of most famous and useful herbals. Ginger belongs to Zingiberaceae family and Zingiber genus (Bhatt et al. 2013; Zadeh and Kor 2014; Bakr et al. 2020). Ginger contains more than 60 active constituents, including gingerols, shogaols, paradols, and even zingerone, and is a good source of essential micronutrients such as potassium, magnesium, copper, manganese, silicone, and small quantities of vitamins such as $\mathrm{A}, \mathrm{E}$ and some quantities of $\mathrm{B}$ and vitamin $\mathrm{C}$ are also present in ginger rhizome (Bhatt et al. 2013). In recent years, several studies have focused on ginger's potential in rumen fermentation modification (El Samarany 2015; Soroor and Moeini 2015; Al-Azazi et al. 2018), but previous studies have not concentrated on ginger's impact on acid-base balance. This study was applied to investigate the effect of ginger powder (Zingiber officinale) $500 \mathrm{mg} / \mathrm{kg}$ bwt orally supplement for 5 days on (acid-base balance), rumen (physical, cellular, and biochemical), and blood constituents in apparently healthy Egyptian sheep.

\section{MATERIALS AND METHODS}

\section{Ethical Approval}

The current study was approved by Veterinary Medicine Cairo University Institutional Animal Care and Use Committee.

Cite This Article as: Zaki MG, Barka TA and Tayeb FAEF, 2021. Effect of ginger powder (Zingiber officinale) on acid-base balance, rumen and blood constituents in healthy Egyptian sheep. International Journal of Veterinary Science 10(1): 55-58. https://doi.org/10.47278/journal.ijvs/2020.007 


\section{Animals and Experimental Design}

A total of 10 apparently healthy non-pregnant Egyptian ewes, belonging to the Department of Medicine and Infectious Diseases, Faculty of Veterinary Medicine, Cairo University, have been used in this study. Their age ranged between 2-4 years and their body weight ranged between $30-40 \mathrm{~kg}$. They administered ginger powder as $500 \mathrm{mg} / \mathrm{kg}$ bwt orally, dissolved in a sufficient quantity of water; in the morning before feeding the traditionally offered ration for 5 days. The dose $500 \mathrm{mg} / \mathrm{kg}$ bwt was determined by Matthews et al. (2016) and Al-Azazi et al. (2018).

\section{Samples}

Blood and rumen juice samples were collected in the morning before feeding on 0 (control), $3^{\text {rd }}$, and $5^{\text {th }}$ day of experiment. Blood samples for acid base balance were collected by puncture of jugular vein on heparin plastic syringe. EDTA vacutainers used for the CBC analysis and plain vacutainers used for serum separation for biochemical analysis. Rumen juice samples $(40 \mathrm{ml})$ were collected using a rubber stomach tube, in dry clean cups. Samples were taken to the laboratory immediately after sampling.

\section{Laboratory Examination}

Blood samples taken by heparin plastic syringes for acid-base balance $\left(\mathrm{pH}, \mathrm{PCO}_{2}, \mathrm{PO}_{2}, \mathrm{HCO}_{3}\right.$, and base excess) were analyzed by using the blood gas analyzer. Samples taken with EDTA vacutainers for CBC estimation were examined manually by using the method described by Wintrobe (1976), and samples taken with plain vacutainers were centrifuged at $4000 \mathrm{rpm} / 10$ minutes then blood serum separated into a clean dried plastic vial and stored at $-18^{\circ} \mathrm{C}$ till chemical analysis. Serum samples examination includes estimation of serum total protein, albumin, Gamma-glutamyltransferase (GGT), Aspartate aminotransferase (AST), blood urea nitrogen (BUN) and serum creatinine, using APEL spectrophotometer - Japan and specific kits produced by Spectrum Company- Egypt. Globulin and $(\mathrm{A} / \mathrm{G})$ ratio was calculated mathematically. Physical examination of rumen samples includes $(\mathrm{pH}$, odor, color, and consistency) according to Radostits et al. (2007) and microscopic examination includes protozoal activity according to Alonso (1979) were immediately examined. Then samples were sieved through 4 folds of sterile gauze, $2 \mathrm{ml}$ fixed with strong acids used to determine concentrations of volatile fatty acids by Macro Kgeldahl steam distillation method described by Eadie et al. (1967), $2 \mathrm{ml}$ used to determine ammonia $\mathrm{N}_{2}$ concentration by using APEL spectrophotometer- Japan and specific kits produced by Biodiagnostics CompanyEgypt, and $2 \mathrm{ml}$ fixed and stained with methylene green formal saline for total protozoal count according to the method of Ito et al. (1994).

\section{Statistical Analysis}

Statistical analysis was carried out by SPSS program version 24, using one-way ANOVA. Results were expressed as mean \pm SD at $\mathrm{P} \leq 0.05$.

\section{RESULTS AND DISCUSSION}

Acid base-balance parameters (Table 1) showed no significant difference in $\mathrm{pH}, \mathrm{PCO}_{2}, \mathrm{PO}_{2}, \mathrm{HCO}_{3}{ }^{-}$and base excess $(\mathrm{P}>0.05)$ on the $3^{\text {rd }}$ and $5^{\text {th }}$ day of the experiment. Findings of day zero were in agreement with what was recorded by Onmaz et al. (2009) and Hussein and Aamer (2013). This result indicates that ginger didn't affect acid-base balance in the body and maintain it within normal ranges.

Rumen physical, chemical, and microscopical constituents (Table 2) showed Yellowish-brown color, aromatic odor, slimy to slightly viscous consistency in agreement with the findings of Anderson and Rings (2008), Karapinar et al. (2008), and Constable et al. (2017). Non-significant $(\mathrm{P}>0.05)$ differences were noted along the experiment in color, odor and consistency in agreement with the findings of Al-Azazi et al. (2018). Ginger maintained protozoal activity and TPC in agreement with the findings of Al-Azazi et al. (2018) and Abo Bakr (2019). Regarding rumen $\mathrm{pH}$ value, there was a significant increase in $\mathrm{pH}(\mathrm{P}<0.05)$ and the highest value was after the $3^{\text {rd }}$ day, this in agreement with the findings of Taylor (2017) who reported that ginger is one of most alkaline herbs, and contrary to the findings of Zhang et al. (2011), El Samarany (2015) and Al-Azazi et al. (2018) which reported that ginger didn't change rumen $\mathrm{pH}$, and (Al-Khayat 2011) which reported a decrease in rumen $\mathrm{pH}$. The results of rumen biochemical constituents showed significant decrease in TVFAs $(\mathrm{P}<0.05)$ concentration on the $3^{\text {rd }}$ day and increased again on the $5^{\text {th }}$ day of treatment similar to the findings of Zhang et al. (2011). Thus, suggesting that rumen microbial fermentation was inhibited due to antimicrobial activity of ginger. Soroor and Moeini (2015) recorded no effect on TVFAS, while Al-Azazi et al. (2018) recorded slight increases in TVFAs concentration on the $2^{\text {nd }}$ and $4^{\text {th }}$ day following treatment. There was no significant difference in rumen ammonia N2 concentration $(\mathrm{P}>0.05)$ and Al-Azazi et al. (2018), while El Samarany 2015) and Soroor and Moeini (2015) reported a significant decrease in ammonia N2 concentration $(\mathrm{P}<0.05)$.

Complete blood count (Table 3) showed nonsignificant difference $(\mathrm{P}>0.05)$ occurred between different days of sampling in RBCs count, hemoglobin, PCV, neutrophils, and MCV along with the findings of Al-Dain and Jarjeis (2015), AL-Jubori (2017), and Al-Azazi (2019), while Hendawy et al. (2019) reported an increase in RBCs count. WBCs and Lymphocytes increased significantly $(\mathrm{P}<0.05)$ in agreement with the findings of Al-Dain and Jarjeis (2015) and Hendawy et al. (2019) and contrary to the finding by Al-Azazi (2019) who found non-significant changes occurred in WBCS. The significant increase in the total WBC may because ginger plays a good role in stimulating inflammatory cells and because ginger containing active ingredients such as gingerdiol and gingerols which have antioxidant activity (Zancan et al. 2002; Lin et al. 2003). The significant increase in the percentage of lymphocytes may be due to active compounds such as gingerols, it increases the body's defense mechanism, particularly the percentage of BLymphocytes cells (Al-Dain and Jarjeis 2015). MCHC and $\mathrm{MCH}$ showed a significant increase $(\mathrm{P}<0.05)$, while Hendawy et al. (2019) reported no-significant $(\mathrm{P}>0.05)$ differences in MCHC percentages. 
Int J Vet Sci, 2021, 10(1): 55-58

Table 1: Effect of ginger supplementation on Acid-base balance parameters on different days.

\begin{tabular}{lcrc}
\hline Variables & 0 day (control) & $3^{\text {rd }}$ day & $5^{\text {th }}$ day \\
\hline $\mathrm{pH}$ & $7.46 \pm 0.02 \mathrm{a}$ & $7.46 \pm 0.03 \mathrm{a}$ & $7.46 \pm 0.02 \mathrm{a}$ \\
$\mathrm{PCO}_{2}(\mathrm{mmHg})$ & $41.60 \pm 1.56 \mathrm{a}$ & $41.40 \pm 1.00 \mathrm{a}$ & $42.00 \pm 1.55 \mathrm{a}$ \\
$\mathrm{PO}_{2}(\mathrm{mmHg})$ & $53.80 \pm 9.48 \mathrm{a}$ & $47.00 \pm 1.52 \mathrm{a}$ & $42.20 \pm 0.87 \mathrm{a}$ \\
$\mathrm{HCO}(\mathrm{mmol} / \mathrm{l})$ & $29.00 \pm 1.17 \mathrm{a}$ & $29.80 \pm 1.58 \mathrm{a}$ & $29.00 \pm 0.75 \mathrm{a}$ \\
$\mathrm{BE}(\mathrm{mmol} / \mathrm{l})$ & $4.76 \pm 1.39 \mathrm{a}$ & $5.22 \pm 1.94 \mathrm{a}$ & $4.70 \pm 0.92 \mathrm{a}$ \\
\hline
\end{tabular}

Values (mean $\pm \mathrm{SD})$ within the same row having common letter are not significantly $(\mathrm{P}<0.05)$ different.

Table 2: Effect of ginger supplementation on physical, cellular and biochemical constituents of rumen fluid on different days.

\begin{tabular}{lccc}
\hline Variables & 0 day $($ control $)$ & $3^{\text {rd }}$ day & $5^{\text {th }}$ day \\
\hline Protozoal activity & ++ to +++ & ++ to +++ & +++ \\
TPC $\left(\times 10^{4} / \mathrm{ml}\right)$ & $41.80 \pm 6.17 \mathrm{a}$ & $54.20 \pm 8.01 \mathrm{a}$ & $66.20 \pm 13.28 \mathrm{a}$ \\
pH & $7.20 \pm 0.11 \mathrm{~b}$ & $7.82 \pm 0.09 \mathrm{a}$ & $7.54 \pm 0.07 \mathrm{a}$ \\
TVFAS $(\mathrm{mmol} / \mathrm{L})$ & $60.30 \pm 3.36 \mathrm{a}$ & $37.04 \pm 2.58 \mathrm{~b}$ & $50.16 \pm 2.26 \mathrm{a}$ \\
Ammonia N2 (mmol/L) & $7.70 \pm 0.56 \mathrm{a}$ & $5.70 \pm 0.86 \mathrm{a}$ & $7.13 \pm 1.01 \mathrm{a}$ \\
\hline
\end{tabular}

Values (mean $\pm \mathrm{SD})$ within the same row having common letter are not significantly $(\mathrm{P}<0.05)$ different.

Table 3: Effect of ginger supplementation on complete blood count on different days.

\begin{tabular}{lccc}
\hline Variables & 0 day (control) & After (3) days & After (5) days \\
\hline RBCs $\left(\times 10^{6} / \mathrm{cmm}\right)$ & $11.65 \pm 0.57 \mathrm{a}$ & $11.95 \pm 0.44 \mathrm{a}$ & $12.05 \pm 0.43 \mathrm{a}$ \\
Hemoglobin $(\mathrm{mg} / \mathrm{dl})$ & $10.62 \pm 0.37 \mathrm{a}$ & $10.98 \pm 0.40 \mathrm{a}$ & $11.56 \pm 0.22 \mathrm{a}$ \\
PCV $(\%)$ & $36.20 \pm 1.43 \mathrm{a}$ & $36.40 \pm 1.22 \mathrm{a}$ & $37.20 \pm 1.45 \mathrm{a}$ \\
WBCs $\left(\times 10^{3} / \mathrm{cmm}\right)$ & $7.40 \pm 0.22 \mathrm{~b}$ & $9.26 \pm 0.33 \mathrm{a}$ & $8.72 \pm 0.18 \mathrm{a}$ \\
Neutrophils $(\%)$ & $23.80 \pm 0.33 \mathrm{a}$ & $24.00 \pm 0.28 \mathrm{a}$ & $23.20 \pm 1.34 \mathrm{a}$ \\
Lymphocytes $(\%)$ & $18.00 \pm 1.13 \mathrm{c}$ & $51.00 \pm 2.56 \mathrm{a}$ & $39.40 \pm 2.07 \mathrm{~b}$ \\
MCV (fl) & $30.52 \pm 0.69 \mathrm{a}$ & $28.58 \pm 0.17 \mathrm{a}$ & $28.98 \pm 0.63 \mathrm{a}$ \\
MCH (pg) & $8.98 \pm 0.41 \mathrm{~b}$ & $11.10 \pm 0.29 \mathrm{a}$ & $11.32 \pm 0.15 \mathrm{a}$ \\
MCHC $(\mathrm{mg} / \mathrm{dl})$ & $29.44 \pm 1.20 \mathrm{~b}$ & $33.18 \pm 0.23 \mathrm{a}$ & $33.42 \pm 0.20 \mathrm{a}$ \\
\hline
\end{tabular}

Values (mean \pm SD) within the same row having common letter are not significantly $(\mathrm{P}<0.05)$ different.

Table 4: Effect of ginger supplementation on Serum biochemical constituents on different days.

\begin{tabular}{lccc}
\hline Variables & 0 day (control) & After (3) days & After (5) days \\
\hline AST (units/ml) & $66.20 \pm 1.28 \mathrm{a}$ & $84.20 \pm 12.63 \mathrm{a}$ & $104.40 \pm 14.61 \mathrm{a}$ \\
GGT (Units/ml) & $27.20 \pm 2.69 \mathrm{a}$ & $29.60 \pm 5.22 \mathrm{a}$ & $41.60 \pm 7.39 \mathrm{a}$ \\
Total protein $(\mathrm{g} / \mathrm{dl})$ & $7.10 \pm 0.13 \mathrm{a}$ & $5.92 \pm 0.22 \mathrm{~b}$ & $5.84 \pm 0.37 \mathrm{~b}$ \\
Albumin $(\mathrm{g} / \mathrm{dl})$ & $2.87 \pm 0.07 \mathrm{a}$ & $2.88 \pm 0.07 \mathrm{a}$ & $2.90 \pm 0.04 \mathrm{a}$ \\
Globulin $(\mathrm{g} / \mathrm{dl})$ & $4.23 \pm 0.07 \mathrm{a}$ & $3.04 \pm 0.23 \mathrm{~b}$ & $2.94 \pm 0.39 \mathrm{~b}$ \\
A/G & $0.68 \pm 0.01 \mathrm{a}$ & $0.98 \pm 0.10 \mathrm{a}$ & $1.15 \pm 0.25 \mathrm{a}$ \\
BUN (mg/dl) & $19.60 \pm 1.46 \mathrm{a}$ & $17.20 \pm 0.95 \mathrm{a}$ & $20.80 \pm 1.48 \mathrm{a}$ \\
Creatinine $(\mathrm{mg} / \mathrm{dl})$ & $1.47 \pm 0.15 \mathrm{a}$ & $1.64 \pm 0.07 \mathrm{a}$ & $1.41 \pm 0.13 \mathrm{a}$ \\
\hline
\end{tabular}

Values (mean $\pm \mathrm{SD})$ within the same row having common letter are not significantly $(\mathrm{P}<0.05)$ different.

Serum constituents (Table 4) showed significant decrease $(\mathrm{P}<0.05)$ in total serum protein and globulin on $3^{\text {rd }}$ and $5^{\text {th }}$ days compared to day zero of the experiment, the peak of decrease occurred after the $5^{\text {th }}$ day, in agreement with the findings of Al-Homidan (2005), but Al-dain and Jarjeis (2015), Al-Azazi et al. (2018) and Abo Bakr (2019) reported significant increases $(\mathrm{P}<0.05)$ in total proteins and globulin after ginger powder supplementation. Serum albumin showed no significant difference $(\mathrm{P}>0.05)$ between experiment days, in agreement with the findings of AlAzazi et al. (2018) and contrary to the findings reported by EL-Gohary et al. (2012) which reported an increase in serum albumin. Regarding serum A/G ratio, no significant difference $(\mathrm{P}>0.05)$ was noted in the $\mathrm{A} / \mathrm{G}$ ratio compared to day zero, while Al-Azazi et al. (2018) reported significant decrease $(\mathrm{P}<0.05)$ on the $5^{\text {th }}$ day in $A / G$ ratio compared to day zero. Blood urea nitrogen had no significant difference between different sampling days because ruminal concentration of NH3-N was not affected by the addition of ginger in our study, so no changes in plasma urea-N concentration were expected (Petit and Flipot 1992; Davidson et al. 2003). These findings in agreement with the findings of Al-Azazi et al. (2018) and contrary to the findings of EL Gohary et al. (2012) which reported a significant increase $(\mathrm{P}<0.05)$ in $\mathrm{BUN}$. Serum creatinine, AST and GGT showed no significant difference between the different sampling days. In this connection EL-Gohary et al. (2012), Al-dain and Jarjeis (2015) and Al-Azazi et al (2018), while Abo Bakr (2019) found substantial increases in creatinine, AST and GGT. These results indicated that ginger didn't affect the organs function. The observed variation in all these parameters may be attributed to variations in species, doses, preparation, and factors affecting absorption from the gut.

\section{Conclusion}

Ginger powder (Zingiber officinale) $500 \mathrm{mg} / \mathrm{kg}$ bwt orally giving in sheep for 5 days, maintained acid-base balance, increased rumen $\mathrm{pH}$, WBCs, and lymphocytes. Concerning changes in blood and rumen constituents, we can recommend using ginger supplementation as $500 \mathrm{mg} / \mathrm{kg}$ bwt orally for 3-5 days as an immune stimulant and in the treatment of rumen acidosis and respiratory affections in sheep. Further investigation should be applied on diseased cases to confirm the effect of ginger as a therapeutic agent in such cases. 


\section{Author's Contribution}

Zaki MG, performed animal treatments, blood samples and rumen fluid collection, and data analysis. Baraka TA, designed the experiments and also wrote the manuscript. Tayeb FA, reviewed the manuscript. All authors reviewed and approved the final version.

\section{REFERENCES}

Abo Bakr S, 2019. Effect of adding ginger powder or ginger oil on productive performance of ewes during lactation period. Egyptian Journal of Nutrition and Feeds 22: 63-78. https://doi.org/10.21608/EJNF. 2019.75841

Al-Azazi AS, Tayeb FA, Baraka TA and Khalaf AM, 2018. Effect of ginger powder (Zingiber Officinale) on selected rumen and blood serum constituents in sheep. Indian Journal of Applied Research 8: 27-30.

Al-Azazi AS, 2019. Clinical and Therapeutic Studies on Digestive Disorders Using Selected Phytogenic Products in Sheep Thesis, Faculty of Veterinary Medicine, Cairo University, Egypt.

Al-dain QZ and Jarjeis EA, 2015. Vital impact of using ginger roots powder as feed additive to the rations of local Friesian dairy cows and its effect on production \& economic efficiency of milk and physiological of blood. Kufa Journal of Veterinary Medical Sciences 6: 154-165.

AL-Homidan AA, 2005. Efficacy of using different levels of Allium sativum and Zingiber officinale on broiler chicks performance. Saudi Journal of Biological Sciences 12: 96-102.

AL-jubori OS, 2017. Synergistic effect of ginger, propolis added to concentrated diet on some production and physiological characteristics of the Awassi ewes. Iraqi Journal of Agricultural Sciences 48: 252-255. https://doi.org/ $\underline{10.36103 / \text { ijas.v48i2.425 }}$

Al-Khayat DA, 2011. Effect of using Zingiber officinale in the activity and account of bacteria and parasital protozoa and echological status of rumen of Awassi ewes. Al-Anbar Journal of Veterinary Sciences 4: 60-66.

Alonso A, 1979. Diagnostic analysis of rumen fluid. The Veterinary Clinics of North America. Large Animal Practice 1: 363-376. https://doi.org/10.1016/s0196-9846(17)30189-1

Anderson DE and Rings M, 2008. Current Veterinary Therapy: Food Animal Practice, Elsevier Health Sciences; pp: 715.

Bakr AF, Abdelgayed SS, EL-Tawil OS and Bakeer AM, 2020. Ginger extract and ginger nanoparticles; characterization and applications. International Journal of Veterinary Science 9: 203-209.

Bhatt N, Waly MI, Essa MM and Ali A, 2013. Ginger: A functional herb. Food as Medicine. Nova Science Publishers, Inc., New York, USA, pp: 51-71.

Constable PD, Hinchcliff KW, Done SH and Grunberg W, 2017. Veterinary Medicine. A Textbook of the Diseases of Cattle, Horse, Sheep, Pigs and Goats 11Th Ed. Elsevier Saunders. https://doi.org/10.1016/b978-0-7020-5246-0.00033-4

Davidson S, Hopkins BA, Diaz DE, Bolt SM, Brownie C, Fellner V and Whitlow LW, 2003. Effects of amounts and degradability of dietary protein on lactation, nitrogen utilization, and excretion in early lactation Holstein cows. Journal of Dairy Science 86: 1681-1689. https://doi.org/10.3168/jds.s0022-0302(03)73754-0

Eadie JM, Hobson P and Mann S, 1967. A note on some comparisons between the rumen content of barley-fed steers and that of young calves also fed on a high concentrate ration. Animal Science 9: 247-250. https://doi.org/10.1017/s0003356100038514

EL-Gohary E, EL-Saadany SA, Abd-Elkhabeer MA and Aiad M, 2012. Effect of supplementing some medicinal herbs and plants on the performance of lactating goats: 1- productive and reproductive performance. Journal of Animal and
Poultry Production, Mansoura University 3: 199-213. https://doi.org/10.21608/jappmu.2012.82788

El samarany WH, 2015. Effect of crushed ginger root feeding on rumen fluid characters and digestion efficiency in Awasi sheep. Egyptian Journal of Nutrition and Feeds 18: 39-42.

Engel C, 2007. Zoopharmacology In: Wynn S.G, and Fougere (Eds). Veterinary Herbal medicine. Library of Congress Cataloging-in Publication Data 695p.

FAOSTAT, 2018. Retrieved from: http//faostat.org

Hendawy AO, Mansour MM, and El-Din AN, 2019. Effects of medicinal plants on haematological indices, colostrum, and milk composition of ewes. Journal of Veterinary Medicine and Animal Sciences 2: 1-5.

Hussein HA and Aamer AA, 2013. Influence of different storage times and temperatures on blood gas and acid-base balance in ovine venous blood. Open Veterinary Journal 3: 1-7.

Ito A, Imai S, and Ogimoto K, 1994. Rumen ciliate composition and diversity of Japanese beef black cattle in comparison with those of Holstein-Friesian cattle. Journal of Veterinary Medical Science 4: 707-714. https://doi.org/10.1292/ jvms.56.707

Karapinar T, Dabak M, Kizil O and Balikci E, 2008. Severe thiamine deficiency in sheep with acute ruminal lactic acidosis. Journal of Veterinary Internal Medicine 22: 662665. https://doi.org/10.1111/j.1939-1676.2008.0094.x

Lin N, Huo G, Zhang L and Zhang X, 2003. Effect of Zingiber officinale Rosc. on Lipid peroxidation in hyperlipidemia rats. Journal of Hygiene Research 32: 22-23.

Matthews KK, O'Brien DJ, Whitley NC, Burke JM, Miller JE and Barczewski RA, 2016. Investigation of possible pumpkin seeds and ginger effects on gastrointestinal nematode infection indicators in meat goat kids and lambs. Small Ruminant Research 136: 1-6. https://doi.org/10.1016/j.smallrumres.2015.12.036

Onmaz AC, Gunes V, Atalan G Ü, Gelfert CC and Atalan G Ü, 2009. Comparison of arterial and venous blood gas values in sheep before and during isoflurane anaesthesia. Revue de Médecine Vétérinaire 160: 356-361.

Petit HV and Flipot PM, 1992. Feed utilization of beef steers fed grass as hay or silage with or without nitrogen supplementation. Journal of Animal Science 70: 876-883. https://doi.org/10.2527/1992.703876x

Radostits OM, Gay CC, Hinchcliff KW, Constable PD, Jacobs DE, Ikede BO, McKenzie RA, Colwell D, Osweiler G and Bildfell RJ, 2007. Veterinary Medicine: A Textbook of the Diseases of Cattle, Sheep, Pigs, Goats and Horses.

Soroor ME and Moeini M M, 2015. The influence of ginger (Zingiber Officinale) on in vitro rumen fermentation patterns. Annual Research \& Review in Biology 5: 54-63. https://doi.org/10.9734/arrb/2015/12495

Taylor k, 2017. Acid-alkaline spices and herbs food chart, Retrived from: https://foodary.com/85/acid-alkaline-spicesand-herbs-food-chart/

Wintrobe MM, 1976. Classics: Macroscopic examination of the blood by MM. Wintrobe, MD, Ph.D. American journal of the Medical Sciences 90-101. https://doi.org/10.1097/ 00000441-197601000-00014

Zadeh JB and Kor NM, 2014. Physiological and pharmaceutical effects of Ginger (Zingiber officinale Roscoe) as a valuable medicinal plant. European Journal of Experimental Biology 4: 87-90.

Zancan KC, Marques MO, Petenate AJ and Meireles MA, 2002. Extraction of ginger (Zingiber officinale Roscoe) oleoresin with $\mathrm{CO} 2$ and co-solvents: A study of the antioxidant of the extracts. The Journal of supercritical fluids 24: 57-67. https://doi.org/10.1016/s0896-8446(02)00013-x

Zhang TT, Yang ZB, Yang WR, Jiang SZ and Zhang GG, 2011. Effects of dose and adaptation time of ginger root (Zingiber officinale) on rumen fermentation. Journal of Animal and Feed Sciences 20: 461-471. https://doi.org/10.22358/ jafs/66200/2011 